\title{
Diversity and community structure of dung beetles (Coleoptera: Scarabaeinae) associated with semi-urban fragmented agricultural land in the Malabar coast in southern India
}

\author{
K. Simi Venugopal ${ }^{1}$, Sabu K. Thomas ${ }^{2} \&$ Albin T. Flemming ${ }^{3}$ \\ 1,3 Post Graduate and Research Department of Zoology, Loyola College, Chennai, Tamil Nadu 600034, India \\ ${ }^{2}$ Post Graduate and Research Department of Zoology, St. Joseph's College, Devagiri, Kozhikode, Kerala 673008, India \\ Email: ${ }^{1}$ simisachin@gmail.com, ${ }^{2}$ sabukthomas@gmail.com (corresponding author), ${ }^{3}$ dratfleming@gmail.com
}

Date of publication (online): 26 July 2012 Date of publication (print): 26 July 2012 ISSN 0974-7907 (online) | 0974-7893 (print)

Editor: B.B. Hosetti

\section{Manuscript details:}

Ms \# 03074

Received 20 January 2012

Final received 09 May 2012

Finally accepted 29 May 2012

Citation: Venugopal, K.S., S.K. Thomas \& A.T Flemming (2012). Diversity and community structure of dung beetles (Coleoptera: Scarabaeinae) associated with semi-urban fragmented agricultural land in the Malabar coast in southern India. Journal of Threatened Taxa 4(7): 2685-2692.

Copyright: (c) K. Simi Venugopal, Sabu K. Thomas \& Albin T. Flemming 2012. Creative Commons Attribution 3.0 Unported License. JoTT allows unrestricted use of this article in any medium for non-profit purposes, reproduction and distribution by providing adequate credit to the authors and the source of publication.

Author Details: Mrs. K. SIMI Venugopal is pursuing her $\mathrm{PhD}$ programme on the ecology and systematics of dung beetles at Post Graduate and Research Department of Zoology, Loyola College, Chennai, Tamil Nadu, India.

Dr. SABU K. Thomas is an associate professor attached to Post Graduate and Research Department of Zoology, St. Joseph's College, Devagiri, Kozhikode, Kerala and systematics and ecology of ground beetles in the moist south Western Ghats is his thrust area.

Dr. Albin T. Fleming, associate professor and head of the Post Graduate and Research Department of Zoology, Loyola College, Chennai, Tamil Nadu and is actively engaged with the systematic of various insect groups in peninsular India.

Author Contribution: Taxonomic analysis, sampling and data analysis by the first and second authors; discussion by all the three authors.

Acknowledgments: The financial assistance provided by UGC (University Grants Commission, India), is gratefully acknowledged.

\section{(c) (i) (口)}

\section{OPEN ACCESS | FREE DOWNLOAD}

\begin{abstract}
An evaluation of the diversity and community structure of dung beetles associated with semiurban agricultural land in the Malabar coast of southern India revealed that urbanization has led to decreased diversity compared to regional forests, and has affected the community status of dung beetles. However, contrary to expectations, species richness was observed to be equivalent to rural agricultural fields in the region. Low abundance of prominent agricultural habitat species indicates that the study area has changed as a result of habitat modification/urbanization, and the prevailing conditions are not ideal for the establishment of the most common species in agriculture belts. Prominence of two less common species, Tiniocellus spinipes and Caccobius vulcanus, indicates these generalist urban adaptable (synanthropic) species have become increasingly widespread and locally abundant. The low abundance of tunnelers and rollers is attributed to fragmentation of the urban agricultural belt, low mammalian diversity and dung availability, and the hard nature of the laterite soil in the Malabar coast region.
\end{abstract}

Keywords: Dung beetles, fragmentation, Malabar coast, southern India, Tiniocellus spinipes, urbanization

\section{INTRODUCTION}

Destruction and deterioration of natural habitats associated with urbanization has led to dramatic changes in the biotic structure and composition of ecological communities. Observations include decreased abundance and diversity, disappearance or replacement of indigenous species by non-natives (Blair 1996, 2004; La Sorte \& Boecklen 2005) and habitat specialists (Magura et al. 2010), and local extinctions (Raupp et al. 2010). In many places, although highly modified and disturbed, small urban fragments of agricultural lands in the midst of urban environments have been identified as an important source of native biodiversity (Gaston et al. 2004). The different fauna found in small urban fragments may be a consequence of any of a number of pressures associated with fragmentation and urbanization, including increased anthropogenic disturbance, reduced area, loss of hosts, invasion of new species and release of natural enemies (Yahner 1988). Such areas can provide ephemeral or more permanent habitats for species, dispersal corridors or resting places for migrating organisms (Gaston et al. 2005). Therefore, it is important to document the status of biodiversity prevailing in other areas to identify the level of biodiversity still left in urban areas and characterize the remaining elements of the original biota (e.g. are they specialist or generalist). In the present effort we aim to determine the community structure of dung 
beetles in a small isolated agricultural land in the midst of urban settlements in the coastal Malabar region.

The Malabar coast moist deciduous forests ecoregion - hereafter referred as $\mathrm{MCF}$ - was a swath of lush tropical evergreen forest that extends along the Western Ghats mountains and the Arabian Sea. MCF represents an extreme example of deforestation in the Western Ghats, having undergone major ecological transformations over the last 100 years (Nair 1991; Wikramanayake et al. 2002). MCF has lost more than $95 \%$ of its original vegetation to deforestation during the British rule (Colonial period), cash crop cultivation during the post Colonial period and recent urbanization. Currently, due to the recent wave of urbanization, the agricultural lands are being transferred into urban jungles at alarming rates in the MCF. It is certain that the remaining original biota that took shelter in these pockets will be lost soon. No records exist about the impact of anthropogenic activity on biodiversity in the region and hence we lack crucial historical documentation of the natural communities in MCF which would remain as an important source of information for measuring species extinctions in the area (Brook et al. 2003). The present effort aims to gather data on the composition and guild structure of dung beetle assemblage associated with a fragmented agricultural landscape in the midst of an urban environment in Kozhikode region in the MCF. We selected dung beetles because they showed significant changes in species composition and community assemblage following forest fragmentation and habitat disturbances (Nichols et al. 2007), making them excellent biodiversity indicators for examining the responses of species communities to anthropogenic disturbance (Gardner et al. 2008a,b). We propose that the regional dung beetle fauna might not have been affected by urbanisation, disappearance of native mammals and an unchanged native assemblage with high diversity and abundance exists in the region.

\section{MATERIALS AND METHODS}

\section{Study area}

Selected study site was an open agricultural field $\left(11^{\circ} 15^{\prime} \mathrm{N} \& 75^{\circ} 48^{\prime} \mathrm{E}\right)$ of predominantly coconut plantation with the intervening grasslands close to Devagiri College campus, Kozhikode used for cattle and sheep grazing. Annual temperature $24-32{ }^{\circ} \mathrm{C}$; relative humidity $40-80 \%$; average rainfall $750-1500$ $\mathrm{mm} /$ year which occurs mostly in the wet months of June to November (CWRDM 2008-09).

\section{Sampling}

Dung beetles were collected using dung baited pitfall traps of the bait-surface-grid type on a seasonal basis during southwest monsoon (June-August), northeast monsoon (September-November), presummer (December-February) and summer (March-May) periods from June 2008 to May 2009. Pit fall traps were made of plastic basins, $10 \mathrm{~cm}$ in diameter and $15 \mathrm{~cm}$ deep and a mixture of water-formalin-liquid soap mixture were used as preservative. The basins were buried with their rim in level with the surrounding substrate and each trap was topped with a plastic plate supported on iron bars to prevent desiccation during sunny days and inundation during the periods of rain. Two hundred grams of fresh cow dung was placed on a wire grid between the basin and the tray. Ten such traps at $50 \mathrm{~m}$ intervals along a linear transect were placed following the standardized dung-beetle sampling design of maintaining a minimum distance of $50 \mathrm{~m}$ between traps to minimize trap interference (Larsen \& Forsyth 2005). Beetles were collected at 0600 and $1600 \mathrm{hr}$ each day. Both diurnal and nocturnal collections were made separately.

Beetles were identified to species levels using taxonomic keys available in Arrow (1931), Balthasar (1963) and by comparing with the verified specimens. After identification, specimens were deposited in the insect collections of St. Joseph's College, Devagiri, Kozhikode. The species were sorted into three functional guilds - dwellers (endocoprids), rollers (telecoprids) and tunnelers (paracoprids) following Cambefort \& Hanski (1991) and three temporal guilds (noctural/diurnal/generalists) following Krell et al. (2003). Species that were present during all seasons with $>10 \%$ abundance were treated as major groups, $<10 \%$ were treated as minor groups and singletons as rare groups. Based on size, dung beetles are classified into small beetles (with size $5 \mathrm{~mm}$ and less) and large beetles (5.1 and $30 \mathrm{~mm})$.

\section{Data analysis}

Diversity (Magurran 2004) was estimated using Shannon-Weaver diversity index (Shannon \& Weaver 
1949), evenness with Simpson's evenness index (Simpson 1949) and richness with Margalef's species richness index (d). Data used for statistical analysis were tested for normality with GRETL open source software version 1.1 (Cottrell 2006). Significant levels of variation in the overall and species-wise abundance with seasons were tested with Kruskal-Wallis followed by Mann-Whitney U test (Weiss 2007). All statistical data analyses were done with Mega Stat Version 10.0 software (Orris 2005) and diversity analysis with Primer v5.2.9 software.

\section{RESULTS}

\section{Species richness and diversity}

A total of 519 dung beetles representing 26 species, belonging to eight genera and five tribes were recorded. Assemblage consisted of three major species, 17 minor and six rare species. Tiniocellus spinipes (44.89\%) and Caccobius vulcanus (17.92\%) dominated the assemblage (Image 1). Large and small size beetles varied in abundance (Kruskal-Wallis test, $\mathrm{H}=8.64$, $\mathrm{df}=1, \mathrm{P}<0.05)$. Small sized beetles represented by 10 species $(67.83 \%$ of total abundance) dominated the assemblage over the large sized beetles represented by 15 species (Table 1 ). The diversity $(\mathrm{H})$ was 2.015 , Margalef species richness index value (d) was 9.75,

Table 1. Abundance (mean $\pm S D$ ), percentage composition, seasonality, temporal and functional guild of dung beetle assemblage in the fragmented urban agricultural habitat during the 2008-09 period.

\begin{tabular}{|c|c|c|c|c|c|c|}
\hline & Species & Mean $\pm S D$ & $\%$ & Seasonality & Temporal guild & Functional guild \\
\hline 1 & Tiniocellus spinipes *@ & $5.83 \pm 6.91$ & 45.87 & $\mathrm{~s}$ & $\mathrm{Di}$ & D \\
\hline 2 & Caccobius vulcanus*\# & $2.33 \pm 3.55$ & 18.31 & $\mathrm{~s}$ & $\mathrm{~N}$ & $\mathrm{~T}$ \\
\hline 3 & Tibiodrepanus setosus *\# & $1.20 \pm 2.10$ & 9.45 & AS & $\mathrm{Di}$ & D \\
\hline 4 & Onthophagus ensifer@ & $0.48 \pm 0.91$ & 3.74 & S & N & $\mathrm{T}$ \\
\hline 5 & Onthophagus falsus @ & $0.48 \pm 0.91$ & 3.74 & $\mathrm{~s}$ & $\mathrm{~N}$ & $\mathrm{~T}$ \\
\hline 6 & Paracopris signatus @ & $0.40 \pm 0.81$ & 3.15 & S & $\mathrm{N}$ & $\mathrm{T}$ \\
\hline 7 & Onthophagus insignicollis \# & $0.30 \pm 0.76$ & 2.36 & S & G & $\mathrm{T}$ \\
\hline 8 & Ochicanthon murthyi\# & $0.28 \pm 0.88$ & 2.12 & AS & $\mathrm{N}$ & $\mathrm{R}$ \\
\hline 9 & Caccobius meridionalis" \# & $0.25 \pm 0.59$ & 1.97 & AS & G & $\mathrm{T}$ \\
\hline 10 & Onthophagus centricornis \# & $0.20 \pm 0.56$ & 1.57 & AS & G & $\mathrm{T}$ \\
\hline 11 & Onthophagus fasciatus @ & $0.18 \pm 0.45$ & 1.38 & AS & G & $\mathrm{T}$ \\
\hline 12 & Onthophagus malabariensis \# & $0.18 \pm 0.50$ & 1.38 & AS & $\mathrm{Di}$ & $\mathrm{T}$ \\
\hline 13 & Onthophagus kchatriya @ & $0.15 \pm 0.43$ & 1.18 & S & $\mathrm{Di}$ & $\mathrm{T}$ \\
\hline 14 & Sisyphus neglectus @ & $0.13 \pm 0.46$ & 0.98 & $\mathrm{~s}$ & $\mathrm{Di}$ & $\mathrm{R}$ \\
\hline 15 & Onthophagus duporti@ & $0.13 \pm 0.40$ & 0.98 & AS & G & $T$ \\
\hline 16 & Onthophagus bifasciatus @ & $0.10 \pm 0.30$ & 0.79 & AS & $\mathrm{N}$ & $\mathrm{T}$ \\
\hline 17 & Sisyphus longipes \# & $0.08 \pm 0.27$ & 0.59 & AS & $\mathrm{Di}$ & $\mathrm{R}$ \\
\hline 18 & Onthophagus cervus@ & $0.08 \pm 0.27$ & 0.59 & AS & $G$ & $\mathrm{~T}$ \\
\hline 19 & Onthophagus unifasciatus @ & $0.05 \pm 0.22$ & 0.39 & AS & $\mathrm{Di}$ & $T$ \\
\hline 20 & Onthophagus dama@ & $0.05 \pm 0.32$ & 0.39 & AS & G & $\mathrm{T}$ \\
\hline 21 & Paracopris davisoni @ & $0.03 \pm 0.16$ & 0.20 & AS & G & $\mathrm{T}$ \\
\hline 22 & Oniticellus cinctus@ & $0.03 \pm 0.16$ & 0.20 & AS & G & D \\
\hline 23 & Onthophagus pygmaeus \# & $0.03 \pm 0.16$ & 0.20 & AS & $\mathrm{Di}$ & $T$ \\
\hline 24 & Onthophagus favrei @ & $0.03 \pm 0.16$ & 0.20 & AS & $\mathrm{Di}$ & $\mathrm{T}$ \\
\hline 25 & Onthophagus madoqua \# & $0.03 \pm 0.16$ & 0.20 & AS & $\mathrm{Di}$ & $\mathrm{T}$ \\
\hline 26 & Onthophagus turbatus @ & $0.03 \pm 0.16$ & 0.20 & AS & $\mathrm{N}$ & $\mathrm{T}$ \\
\hline
\end{tabular}

N - nocturnal; Di - diurnal; G - generalist; * - major species; S - seasonal; AS - aseasonal; \# - small species; @ - large species; D - dweller; T - tunneler; $\mathrm{R}$ - roller 

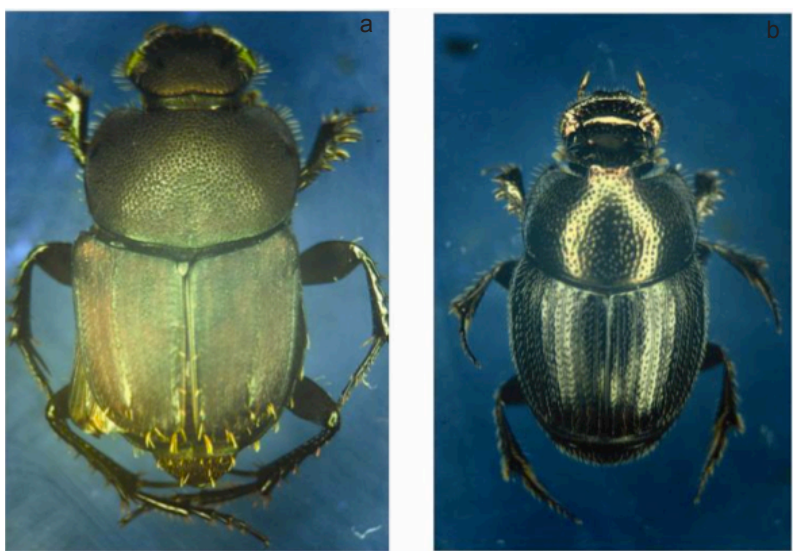

Image 1. Two dominant species (a) Tiniocellus spinipes and (b) Caccobius vulcanus present in the fragmented urban agricultural habitat during 2008-09 period.

dominance index value $(\lambda)$ was 0.24 and evenness (1$\lambda$ ) was 0.751 . Rank of each species based on relative abundance is represented in Fig. 1.

\section{Functional and temporal guild composition}

Dwellers were the most abundant guild (53.75\%) with $T$. spinipes and Tibiodrepanus setosus as dominant species followed by tunnelers $(41.42 \%)$ and rollers $(3.85 \%)(\mathrm{H}=53.46, \mathrm{df}=2, \mathrm{P}<0.05)$. Tunnelers, represented by 20 species $(76.92 \%)$ were the most speciose guild followed by rollers and dwellers represented by three species each (11.53\%) (Table 1). Six species were nocturnal, five were diurnal and 15 were generalists. Diurnal guild dominated the assemblage followed by nocturnal and generalist $(\mathrm{H}=20.01, \mathrm{df}=2, \mathrm{P}<0.05)($ Table 1).

\section{Seasonality}

Highest abundance was recorded during southwest season followed by northeast and summer season $(\mathrm{H}=45.33, \mathrm{df}=3, \mathrm{P}<0.05)$. Among the three guilds, tunnelers were seasonal $(\mathrm{H}=3.81, \mathrm{df}=3, \mathrm{P}<0.05)$ with high abundance during southwest monsoon period followed by northeast monsoon, summer and presummer periods. Dwellers $(\mathrm{H}=4.39, \mathrm{df}=3, \mathrm{P}>0.05)$ and rollers $(\mathrm{H}=11.42, \mathrm{df}=3, \mathrm{P}>0.05)$ did not show any seasonal variation. Eight species (one roller, one dweller and six tunnelers) showed seasonal variation in abundance (Table 2).

\section{DISCUSSION}

Evaluation of the diversity and community structure of the dung beetles associated with the semi-urban agricultural lands revealed that urbanization does cause a decrease in dung beetle diversity compared to regional forests and has affected the community status of dung beetles. However, contrary to the expectations, species richness was in par with the rural agrifields in the region. Following patterns, namely, (1) dominance of the community by two species (T.

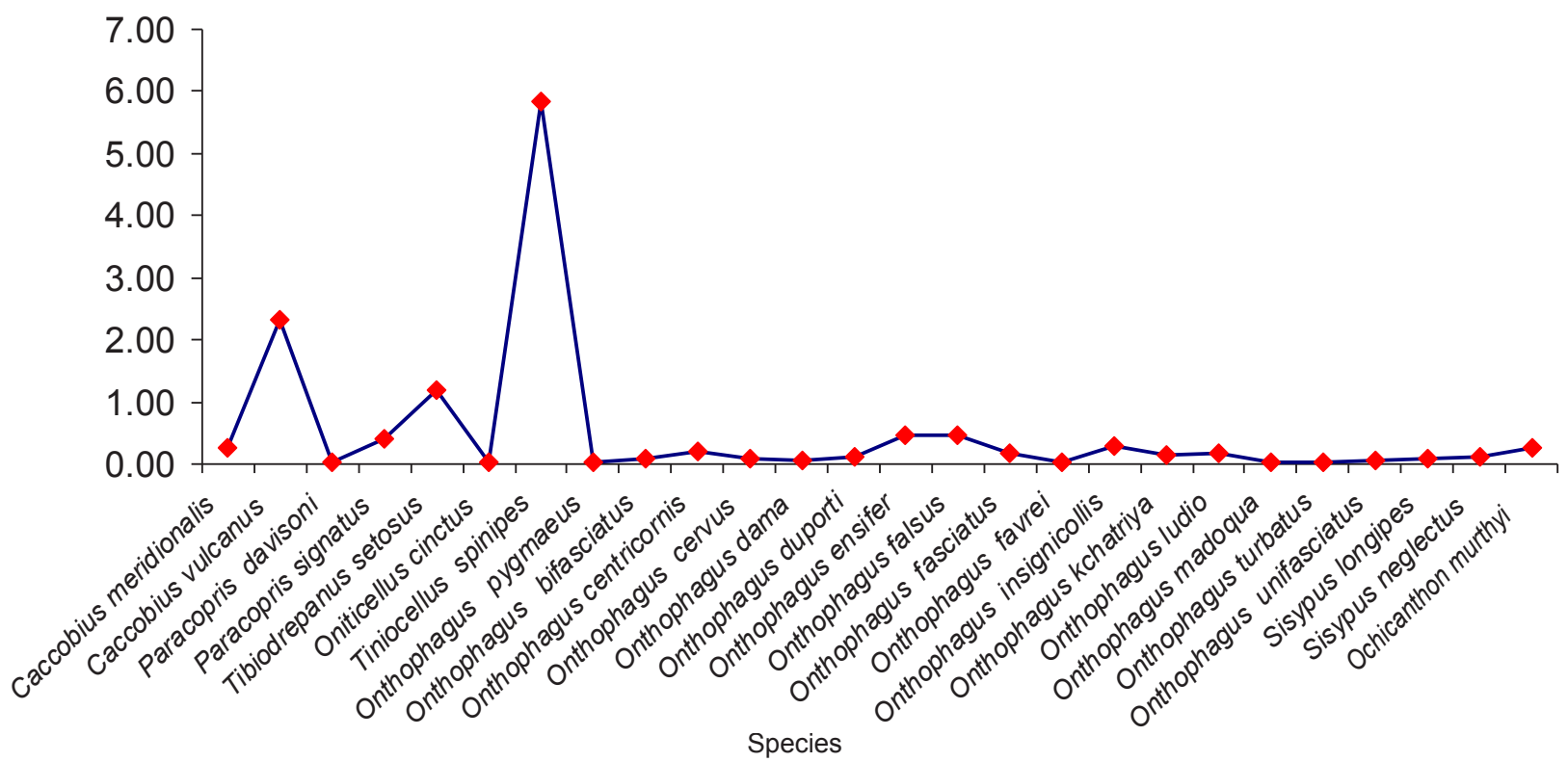

Figure 1. Rank abundance plot of dung beetles in the fragmented urban agricultural habitat during 2008-09 period. 
Table 2. Results of Kruskal-Wallis and Mann-Whitney tests of overall and individual seasonal abundance of dung beetle assemblage in the fragment urban agricultural habitat during 2008-09 period.

\begin{tabular}{|c|c|c|c|c|c|c|c|c|c|c|}
\hline & & \multicolumn{3}{|c|}{ Kruskal-Wallis } & \multicolumn{6}{|c|}{$\begin{array}{l}\text { Mann-Whitney } \\
\text { p-value }\end{array}$} \\
\hline & & H & DF & $p$ - values & S - PS & S - SW & $S-N E$ & PS - SW & PS - NE & SW - NE \\
\hline & Abundance & 20.97 & 3 & $<0.05$ & $>0.05$ & $<0.05$ & $<0.05$ & $<0.05$ & $<0.05$ & $>0.05$ \\
\hline & Species & & & & & & & & & \\
\hline 1 & Caccobius vulcanus & 14.24 & 3 & $<0.05$ & $<0.05$ & $>0.05$ & $>0.05$ & $<0.05$ & $<0.05$ & $>0.05$ \\
\hline 2 & Paracopris signatus & 18.56 & 3 & $<0.05$ & $>0.05$ & $<0.05$ & $>0.05$ & $<0.05$ & $>0.05$ & $<0.05$ \\
\hline 3 & Tiniocellus spinipes & 19.67 & 3 & $<0.05$ & $<0.05$ & $<0.05$ & $>0.05$ & $>0.05$ & $<0.05$ & $<0.05$ \\
\hline 4 & Onthophagus ensifer & 27.76 & 3 & $<0.05$ & $>0.05$ & $<0.05$ & $>0.05$ & $<0.05$ & $>0.05$ & $<0.05$ \\
\hline 5 & Onthophagus falsus & 8.96 & 3 & $<0.05$ & $>0.05$ & $<0.05$ & $>0.05$ & $<0.05$ & $<0.05$ & $>0.05$ \\
\hline 6 & Onthophagus insignicollis & 11.30 & 3 & $<0.05$ & $>0.05$ & $<0.05$ & $>0.05$ & $<0.05$ & $>0.05$ & $>0.05$ \\
\hline 7 & Onthophagus kchatriya & 9.69 & 3 & $<0.05$ & $>0.05$ & $<0.05$ & $>0.05$ & $<0.05$ & $>0.05$ & $>0.05$ \\
\hline 8 & Sisyphus neglectus & 9.47 & 3 & $<0.05$ & $>0.05$ & $<0.05$ & $>0.05$ & $>0.05$ & $>0.05$ & $>0.05$ \\
\hline
\end{tabular}

spinipes and C.vulcanus) recorded rarely from the moist forests and agrifields, and the record of five rare forest specialist species Ochicanthon murthyi, Onthophagus insignicollis, O. kchatriya, O. duporti and Oniticellus cinctus (Arrow 1931; Sabu 2011) and (2) low abundance of prominent species in the regional agrilands and forests namely Caccobius meridionalis, Onthophagus dama, O. turbatus, O. falsus and $O$. fasciatus (Sabu 2011) were observed.

Community structure of the assemblage was highly uneven with the dominance of two species ( $T$. spinipes and C. vulcanus). Uneven distribution of species is relatively common in unstable environments and point towards extreme disturbance (Magurran 2004). Tiniocellus spinipes and C. vulcanus are rare in the agriculture and forest belts of the Western Ghats, and the most abundant species are Caccobius meridionalis, Onthophagus dama, O. turbatus, O. falsus and O. fasciatus (Sabu 2011). Low abundance of these prominent agri habitat species indicates that the study region has changed as a result of the habitat modification/urbanization and the prevailing conditions in the study region is not ideal for the establishment of even the most common and hence the most adapted species in the agriculture belts. Two dominant species in the study region namely $T$. spinipes and $C$. vulcanus are the prominent species in the open semi-arid dry north western part of the Indian subcontinent with a long history of habitat modification (Arrow 1931; Balthasar 1963; Mittal 2005; Kakkar \& Gupta 2010). Higher abundance of two species common in the open and dry belts in northern India and low abundance in the moist regional forest and agri belts indicate them to be heliophilic, open habitats adapted and disturbance tolerant species. Dominance of such heliophilic, dry habitats species in the moist study region indicates that the study region underwent extreme modifications and the utility of these two species can be seen as indicators of habitat change in the MCF in general. Cosmopolitan distribution and common occurance of $T$. setosus in the forests and agribelts in the moist Western Ghats (Sabu 2011) and in the present study MCF site which is an isolated urban agribelt indicates that $T$. setosus is a generalist species with capacity to persist in a wide array of habitat types. Distinctly low representation of forest specialist species supports the 'habitat specialist hypotheses' (Magura et al. 2008), which suggested that 'species richness of forest specialists should decrease from the rural areas to the urban ones and different elements of an assemblage will react differently, because the specialists are expected to decrease with urbanization while the generalist species could be favored (Magura et al. 2004). Results indicate that $T$. spinipes and $C$. vulcanus the generalist urban adaptable (synanthropic) species adapted to the modified urban habitats that have become increasingly widespread and locally abundant. It is likely that these two species may have become increasingly wide spread and locally abundant in different urban regions in the Malabar coast region and are likely to proliferate further in the region at the cost of other species. This type of homogenization of the taxonomic composition 
is a major negative consequence of urbanization world wide (Magura et al. 2010).

In total contrast to the dry habitat dwelling species, occurrence of Ochicanthon species, a rare primitive old world dung beetle species present in moist forest patches ( Krikken \& Huijbregts 2007; Latha et al. 2011) is unexpected. Its presence indicates that the recent habitat modifications in the Western Ghats have not wiped out these relict old world dung beetles (primitive groups) from the agrilands. Similar record of the following rare species namely Onthophagus insignicollis, O. kchatriya, O. duporti and Oniticellus cinctus in the moist Western Ghats indicate that these species represent the sink population of a larger pool of the source, i.e. the native dung beetle population. It is possible that the fragmented agri habitats in the region is a safe microhabitat for such rare species (Onthophagus malabariensis, O. unifasciatus, $O$. pygmaeus, Ochicanthon murthyi) (Magura et al. 2004; Elek \& Lövei 2007) till the gradual disappearance of such habitats.

No record of the large species belonging to the genera Gymnopleurus, Catharsius and Heliocopris in the assemblage indicates that they might have vanished from the region. It could be due to the inability of large dung beetles to withstand dessication and the low survival chance of their larvae in dry soil conditions (Chown 2001). Since the present study was confined to a single site, studies in other similar sites in the region are necessary to establish whether the disappearance of large beetles is a widely applicable pattern.

Dominance of tunnelers in forest and agri habitats, and the higher abundance of the cosmopolitian $T$. setosus is typical of dung beetle assemblages in the Western Ghats (Sabu et al. 2006, 2007; Vinod \& Sabu 2007) and across the globe (Cambefort \& Walter 1991; Andresen 2005). Disappearance leads to the question whether dominance of dweller guild with $T$. spinipes as prominent species is a feature of extremely disturbed habitats in the moist western slopes of the Western Ghats and Malabar coast region. Distinctively high abundance of dwellers over tunnelers and rollers is arising from the unequal abundance of $T$. spinipes. Similar dominance of dwellers with another species (T. setosus) is reported from regions with high dung pad availability as in the elephant dung rich Wayanad forests in the Western Ghats (Vinod 2009) and is attributed to the abundance of elephant/gaur and the resulting dung pad abundance. However there is no record of dominance of dwellers in the agri belts in the Western Ghats. High abundance of dwellers in an agribelt with low dung availability and mammalian diversity is attributed to the low abundance of other guilds (tunnelers/rollers) and the hard nature of the laterite soil in the Malabar coast region which do not favour the population build up of other guilds.

Occurrence of two dominant species $T$. spinipes (diurnal) and $C$. vulcanus (nocturnal) with distinctly contrasting pattern of temporal resource utlilisation patterns as prominent species could be an adaptive strategy for efficient resource partitioning to avoid competition for resources. Such perfect temporal resource partition of the two prominent species could be a major factor that leads to the decline in the abundance of other species. Overall abundance showed distinct seasonality with high abundance during southwest monsoon followed by northeast and summer season. Peak in abundance is linked to the single species dominance of $T$. spinipes which was the most abundant species during southwest monsoon. It is likely that softening of the lateritic soil during the rainy periods could be favouring the abundance of both tunnelers and dwellers. Seasonality of tunnelers, which was the only guild showing seasonality in the region, is additional proof to this assumption.

\section{REFERENCES}

Andresen, E. (2005). Effects of season and vegetation type on community organization of dung beetles in a tropical dry forest. Biotropica 37: 291-300.

Arrow, G.J. (1931). The Fauna of British India including Ceylon and Burma, Col. Lamella III (Coprinae), Taylor and Francis, London, 428pp.

Balthasar, V. (1963). Monographie der Scarabaeidae und Aphodiidae der Palaearktischen und Orientalischen Region (Coleoptera: Lamellicornia). Verlag der Tschechoslowakischen Akademie der Wissenschaften, Prague, Volume I 391pp; Volume II 627pp.

Blair, R.B. (1996). Land use and avian species diversity along an urban gradient. Ecological Applications 6: 506-519.

Blair, R.B. (2004). The effects of urban sprawl on birds at multiple levels of biological organization. Ecology and Society 9(5): 2 Available online: http://www. ecologyandsociety.org/vol9/ iss5/art2.

Brook, B.W., N.S. Sodhi \& P.K. Ng (2003). Catastrophic extinctions follow deforestation in Singapore. Nature 424: 
420-426.

Cambefort, Y. \& P. Walter (1991). Dung beetles in Tropical Forests in Africa, pp. 198-210. In: Hanski, I. \& Y. Cambefort (eds.). Dung Beetle Ecology. Princeton University Press. Princeton, New Jersey.

Chown, S.L. (2001). Physiological variation in insects: hierarchical levels and implications. Journal of Insect Physiology 47: 649-660.

Cottrell, A. (2006). Gretl version 1.1 Gunu general public license department of Economics Wake Forest University. http://www.ecn.wfu.edu./gretl. Accessed on January 2006.

CWRDM (2008-09). Centre for Water Resource Development and Management (CWRDM), weather report 2008-09 Calicut.

Elek, Z. \& G.L. Lövei (2007). Patterns in ground beetle (Coleoptera: Carabidae) assemblages along an urbanization gradient in Denmark. Acta Oecologia 32: 104-111.

Gardner, T.A., M.M.I. Hernadez, J. Barlow \& C.A. Peres (2008a). Understanding the biodiversity consequences of habitat change: The value of secondary and plantation forests for neotropical dung beetles. Journal of Applied Ecology 45: 883-893.

Gardner, T.A., J. Barlow, I.S. Araujo, T.C.S. Avila-Pires, A.B. Bonaldo, J.E. Costa, M.C. Esposito, L.V. Ferreira, J. Hawes, M.I.M. Hemández, M.S. Hoogmoed, R.N. Leite, N.F. Lo-Man-Hung, J.R. Malcolm, M.B. Martins, L.A.M. Mestre, R. Miranda-Santas, A.L. NunesGutjahr, W.L. Overal, L. Parry, S.L. Peters, M.A. Ribeiro-Gunior, M.N.F. da Silva, C. da Silva Mottc \& C. Peres (2008b). The cost-effectiveness of biodiversity surveys in tropical forests. Ecology Letters 11: 139-150.

Gaston, K.J., R.M. Smith, K. Thompson \& P.H. Warren (2004). Gardens and wildlife: the BUGS project. BrWildl 16: $1-9$.

Gaston, K.J., P.H. Warren, K. Thompson \& R.M. Smith (2005). Urban domestic gardens (IV): the extent of the resource and its associated features. Biodiversity and Conservation 14: 3327-3349.

Kakkar, N. \& S.K. Gupta (2010). Diversity and seasonal fluctuations in dung beetle (Coleoptera) community in Kurukshetra, India. Entomological Research 275: 189 192.

Krell, F.T., S. Krell-Westerwalbesloh, I. Weib, P. Eggleton \& K.E. Linsenmair (2003). Spatial separation of Afrotropical dung beetle guilds: a trade-off between competitive superiority and energetic constraints (Coleoptera: Scarabaeidae). Ecography 26: 210-222.

Krikken, J. \& J. Huijbregts (2007). Taxonomic diversity of the genus Ochicanthon in Sundaland (Coleoptera: Scarabaeidae: Scarabaeinae). Tijdschrift voor Entomologie 150: 421-479.

La Sorte, F.A. \& W.J. Boecklen (2005). Temporal turnover of common species in avian assemblages in North America. Journal of Biogeography 32: 1151-1160.

Larsen, T.H. \& A. Forsyth (2005). Trap spacing and transect design for dung beetle biodiversity studies. Biotropica
37(2): 322-325.

Latha, M., G. Cuccodoro, T.K. Sabu \& K.V. Vinod (2011). Taxonomy of the dung beetle genus Ochicanthon Vazde-Mello (Coleoptera: Scarabaeidae: Scarabaeinae) of Indian subcontinent with notes on distribution patterns and flightlessness. Zootaxa 2745: 1-29.

Magura, T., B. Tóthmérész \& T. Molnár (2004). Changes in carabid assemblages along an urbanization gradient in the city of Debrecen, Hungary. Landscape Ecology 19: $747-$ 759 .

Magura, T., G.L. Lövei \& B. Tóthmérész (2008). Time consistent rearrangement of carabid beetle assemblages by an urbanisation gradient in Hungary. Acta Oecologica 34: 233-243.

Magura, T., G.L. Lövei \& B. Tóthmérész (2010). Does urbanization decrease diversity in ground beetle (Carabidae) assemblages? Global Ecology and Biogeography 19: 1626.

Magurran, A.E. (2004). Measuring Biological Diversity. Blackwell Publishing, Oxford, UK, 256pp.

Mittal, I.C. \& N. Kakkar (2005). Community dynamics of dung beetles (Scarabaeidae) in a semi-arid region at Kurukshetra in Northern India, pp. 53-59. In: Gupta, S.R., N.K. Matta, A. Aggarwal, R.K. Kohli \& A.K. Chawla (eds.). Ecology and Environmental Management: Issues and Research Needs 15. National Institute of Ecology, Jaipur and New Delhi.

Nair, S.C. (1991). The Southern Western Ghats - a Biodiversity Conservation Plan. Indian National Trust for Art and Cultural Heritage, New Delhi, 92pp.

Nichols, E., T. Larsen, S. Spector, A.L. Davis, F. Escobar, M. Favila, K. Vulinec \& The Scarabaeinae Research Network (2007). Global dung beetle response to tropical forest modification and fragmentation: a quantitative literature review and meta-analysis. Biological Conservation 137: 1-19.

Orris, J.B. (2005). Megastat version 10.0. Butler University, College of Business Administration, 4600 Sunset Ave, Indianapolis. Distributed by McGraw-Hill. Available online: http://www.mhhe.com/support.

Raupp, M.J., P.M. Shrewsbury \& D.A. Herms (2010). Ecology of herbivorous arthropods in urban landscapes. The Annual Review of Entomology 55: 19-38.

Sabu, T.K., K.V. Vinod \& P.J. Vineesh (2006). Guild structure, diversity and succession of dung beetles associated with Indian elephant dung in South Western Ghats forests Journal of Insect Science 6:17 Available online: http:// insectscience.org/6.17.

Sabu, T.K., K.V. Vinod \& P.J. Vineesh (2007). Succession of dung beetles (Scarabaeinae: Coleoptera) in the dung pats of gaur, Bos gaurus H. Smith (Artiodactyla: Bovidae), from the moist deciduous forests of southern Western Ghats. Biosystematica 1(1): 59-69.

Sabu, T.K. (2011). Guild Structure, Taxonomic Diversity and Biosystematics of Dung Beetles (Coleoptera: Scarabaeinae) in the Agriculture and Forest Habitats of South Western 
Ghats. Project report submitted to University Grant Commission, India.

Shannon, C.E. \& W. Weaver (1949). The Mathematical Theory of Communication. University of Illinois Press. Urbana, IL.

Simpson, E.H. (1949). Measurement of diversity. Nature 163688.

Vinod, K.V. (2009). Studies on the Systematics and Distribution of Dung Beetles (Scarabaeinae: Coleoptera) in the Forests and Agricultural Fields of Wayanad. PhD Thesis. Forest Research Institute University, Dehradun, 214pp.

Vinod, K.V. \& T.K. Sabu (2007). Species composition and community structure of dung beetles attracted to dung of gaur and elephant in the moist forests of South Western Ghats Journal of Insect Science 7.56. Available online: http://insectscience.org/7.56.

Weiss, N.A. (2007). Introductory Statistics-7th Edition. Dorling Kindersley, Pvt. Ltd, India, 984pp.

Wikramanayake, E., E. Dinerstein, C. Loucks, D. Olson, J. Morrison, J. Lamoreux, M. Mcknight \& P. Hedao (2002). Terrestrial Ecoregions of the Indo-Pacific: A Conservation Assessment. Island Press, Washington, 643pp.

Yahner, R.H. (1988). Changes in wildlife communities near edges. Conservation Biology 2: 333-339. 